\title{
MENINGKATKAN KEMAMPUAN MENGENAL ANGKA 1-10 DENGAN MEDIA GAMBAR
}

\author{
Dina Khairiah ${ }^{1}$ \\ IAIN Padangsidimpuan \\ edinna.airi04@gmail.com
Efrida Mandasari Dalimunthe ${ }^{2}$
IAIN Padangsidimpuan
mandasariefrida88@gmail.com \\ Ika Nur Aini Nasution ${ }^{3}$ \\ IAIN Padangsidimpuan \\ ikanuraininasution@gmail.com
}

\begin{abstract}
ABSTRAK
Penelitian ini bertujuan untuk meningkatkan kemampuan mengenal angka 1-10 dengan media gambar di kelas 1 B SD Sihitang. Kemampuan mengenal angka meliputi menyebut angka, menjodohkan angka, dengan gambar dan menulis angka. Jenis penelitian ini adalah penelitian kualitatif yang dilakukan secara kolaboratif dengan tinjauan pustaka. Subyek penelitian adalah anak kelas $1 \mathrm{~B}$ yang berjumlah 15 anak yang terdiri dari 10 anak laki-laki dan 5 anak perempuan. Metode pengumpulan data yang digunakan dalam penelitian ini adalah observasi dan dokumentasi. Teknik analisis data yang digunakan adalah deskriptif kuantitatif. Berdasarkan hasil penelitian dapat disimpulkan bahwa media gambar dapat meningkatkan kemampuan anak dalam mengenal angka 1-10 dengan cara (1) memberi penjelasan untuk gambar dan kemiripannya dengan angka 1-10, (2) melakukan permainan dengan gambar untuk menguatkan ingatan antusiasme anak, dan (3) melakukan berbagai variasi dalam setiap siklus agar anak tidak bosan.
\end{abstract}

Kata Kunci: Mengenal angka 1-10, Media Gambar

Received 06-04-2020; Received in revised 26-12-2020; Accepted 28-12-2020

\begin{abstract}
This study aims to improve the ability to recognize numbers 1-10 with media images in class $1 \mathrm{~B}$ of SD Sihitang. The ability to recognize numbers includes naming numbers, matching numbers, drawing, and writing numbers. This type of research is qualitatively conducted collaboratively with library research. The research subjects were 15th grade B students, consisting of 10 boys and 5 girls. Data collection methods used in this study are observation and documentation. The data analysis technique used is qualitative descriptive. The results showed can be concluded that media images can improve children's ability to recognize numbers $1-10$ by (1) explaining images and their similarities with numbers $1-10,(2)$ playing
\end{abstract}


games with pictures to strengthen the child's enthusiasm, and (3) doing a variety of variations in each cycle so that children do not get bored.

\section{Keywords: Get to know numbers 1-10, Image Media}

\section{A. PENDAHULUAN}

Penelitian yang dilakukan (Qur'aini, 2015) untuk melihat kemampuan mengenal angka 1-10 melalui permainan media bowang di TK Taman Indria Kecamatan Kota Kediri terbukti dengan melakukan tiga tahap dengan hasil akhir (86.7\%) yang mencapai ketuntasan. Maka dapat menjadi simpulan bahwa permainan media bowang dapat diterapkan untuk meningkatkan kemampuan mengenal angka 1-10 anak. Saran, untuk maksud yang sama yaitu upaya meningkatkan kemampuan mengenal angka 1-10, media bowang ini dapat dijadikan pilihan tindakan sebagai pengenalan angka 1-10 pada anak didik.

Penelitian yang dilakukan (Hasiana \& Wirastania, 2017) ini menunjukkan bahwa ada peningkatan dalam kemampuan mengenal bilangan dengan menggunakan program bimbingan media musik ini, menggunakan pre test dan kemudian kelompok melakukan pembelajaran secara konvensional sebanyak enam kali lalu diberikan posttest maka mendapat hasil dilakukan terhadap kelompok kontrol, disimpulkan bahwa sig $(0,107)>0,05$ maka Ho diterima. Artinya, tidak ada perbedaan pada kelompok ini. Pada kelompok kontrol, pembelajaran mengenal angka 1-10 tidak menggunakan kartu angka. Siswa belajar dengan model pembelajaran yang biasa dilakukan sehari-hari. Sedangkan pada kelompok eksperimen, dari hasil penghitungan yang telah dilakukan, dapat diartikan bahwa sig $(0,000)<0,05$ yang berarti ada perbedaan dalam pengenalan angka dengan menggunakan kartu angka.

Adapun penelitian yang dilakukan (Ningrum, 2019) Metode Bermain Kartu Angka Bergambar Untuk Meningkatkan Kemampuan Mengenal Angka 1-10 Pada Kelompok A di PAUD An-Nahdliyah Kenongo Tulangan Sidoarjo melakukan dengan 3 siklus dengan hasil 83,08\% yang mana sudah memenuhi idnikator yang sudah ditetapkan.

Usia dini merupakan masa peka yang sangat penting bagi anak untuk mendapatkan pendidikan yang sesuai dengan umurnya. Pengalaman yang didapatkan dari lingkungannya, termasuk stimulasi yang diberikan akan berpengaruh besar bagi kehidupan anak di masa mendatang. Oleh karena itu, diperlukan upaya yang tepat agar tumbuh kembang anak dapat berlangsung secara optimal dengan memberikan kegiatan pendidikan dan pembelajaran yang sesuai dengan usia, kebutuhan dan minat anak.

Tingkat pencapaian perkembangan kognitif meliputi pengetahuan umum dan sains, konsep bentuk, warna, ukuran, dan pola serta konsep bilangan, angka dan huruf. Dalam Permendiknas Nomor 58 Tahun 2009 (Nasional, 2009), dinyatakan 
J-SANAK: Jurnal Kajian Anak

(p-ISSN: 2686-5343 |e-ISSN: 2715-7989)

Vol. (2)(01), (Juli-Desember) (2020), (Halaman)(40-48)

DOI: https://doi.org/10.24127/j-sanak.v2i01.193

bahwa standar Tingkat Pencapaian Perkembangan lingkup perkembangan kognitif mengenai konsep bilangan dan angka untuk anak usia 5-6 tahun, yang termasuk kelas $1 \mathrm{~B}$, dalam kegiatan Taman kanak-kanak, adalah dapat menyebutkan angka 1-10, dengan menggunakan media konkret ataupun tanpa media. Menurut Vygotsky, anak usia dini masih belum mampu berpikiran abstrak. Bagi anak makna dan obyek berbaur menjadi satu (Mayke, 2007). Anak masih memerlukan benda konkret untuk memahami sesuatu. Mengajarkan membilang pada anak di awali dari hal-hal yang ada disekitar anak, misalnya anak menghitung jumlah pensil yang dibawanya, menghitung jumlah teman di kelasnya dan menghitung jari tangannya. Untuk pembelajaran mengenal angka pada anak diperlukan proses yang berjalan perlahan-lahan, tanpa paksaan, dilakukan dengan santai dan menyenangkan serta dilakukan sambil bermain. Selama ini guru mengenalkan angka 1-10 dengan dua media yaitu kartu angka terbuat dari kertas karton yang dapat dilihat pada gambar dan gambar angka tersebut di tempel di dinding. Kedua media tersebut dirasakan belum efektif untuk meningkatkan kemampuan anak mengenal angka secara optimal. Anak terlihat kurang antusias dan kurang fokus pada kegiatan pembelajaran. Anak mengalihkan perhatiannya dengan bermain dengan temannya. Kondisi yang mendukung tersebut ditambah dengan dilakukannya penggabungan antara kelompok A dan B saat kegiatan pembelajaran. Penulis melakukan observasi terhadap 15 anak kelas 1 B pada tanggal 15 November 2019. Pada kegiatan tersebut penulis melakukan pengamatan saat anak disuruh menyebutkan angka 1-10 dan menulis angka 1-10. Semua mampu dalam melakukannya tetapi belum benar. Pada saat itu peneliti hanya melakukan pengamatan dan belum menggunakan instrumen.

Hasil observasi dengan menggunakan lembar observasi kemampuan anak menyebutkan angka 1-10 tercapai. Kemampuan anak menjodohkan angka dengan gambar belum semua peserta didik mencapainya tetapi masih beberapa orang, selanjutnya untuk kemampuan anak menulis angka 1-10 masih kurang bisa dalam menuliskan angka tersebut. Hasil observasi bahwa anak menyebut angka 1-10 dan menulis angka 1-10 masih kurang baik. Nilai rata-rata anak masih kurang. Anak masih belum lancar dan belum benar dalam menyebut angka 1-10. Dalam penulisan angka 1-10, masih banyak anak yang menulis secara keliru dan terbalik. Berdasarkan kenyataan tersebut, diperlukan adanya langkah perbaikan untuk meningkatkan kemampuan anak dalam mengenal angka 1-10. Diperlukan evaluasi metode pembelajaran yang sudah dipergunakan untuk mengatasi permasalahan tersebut, khususnya untuk meningkatkan kemampuan mengenal angka 1-10. Langkah-langkah inovasi perlu dikenalkan agar terjadi peningkatan kemampuan anak.

Pembelajaran mengenal angka termasuk dalam kategori menghafal. (Sanjaya, 2012) menganjurkan menggunakan "jembatan keledai" untuk mempermudah menghafal. (Ahmadi, 2009) mengungkapkan bahwa penggunaan metode asosiasi sebagai salah satu cara untuk tujuan tersebut. Untuk mengatasi hal ini peneliti 
J-SANAK: Jurnal Kajian Anak

(p-ISSN: 2686-5343 |e-ISSN: 2715-7989)

Vol. (2)(01), (Juli-Desember) (2020), (Halaman)(40-48)

DOI: https://doi.org/10.24127/j-sanak.v2i01.193

mencoba untuk menggunakan media gambar yang diharapkan dapat mendekatkan anak untuk mengingat bentuk benda konkret dan menggunakan metode asosiasi sebagai salah satu cara untuk memudahkan dalam menghafal. Media gambar dalam kegiatan pengenalan angka berupa gambar yang bentuknya mirip dengan angka tertentu seperti gambar pensil atau spidol mirip dengan angka 1. Gambar itik dengan angsa mirip dengan 2. Gambar burung terbang mirip dengan angka 3. Gambar bendera mirip dengan angka 4. Gambar sabit atau gantungan sangkar mirip dengan angka 5. Gambar tunas kelapa atau sendok sayur mirip dengan angka 6 . Gambar tongkat mirip dengan angka 7. Gambar balon yang ada talinya atau raket mirip dengan angka 9 dan gambar spidol dengan telor atau spidol dengan bola mirip angka 10. Dengan menggunakan media gambar anak akan mengingat gambar benda-benda yang ada di sekitar lingkungannya. Ingatan tersebut akan terhubung dengan bentuk angka yang mirip, sehingga diharapkan anak akan lebih mudah mengingat bentuk angka. Berdasarkan masalah di atas, maka penulis menginginkan untuk melihat landasan teoritis dalam pembelajaran dalam mengenalkan angka pada anak usia dini

\section{B. METODOLOGI}

Penelitian ini menggunakan metode penelitian kualitatif studi pustaka dan studi lapangan. Metode penelitian ini menerapkan jenis kualitatif melalui studi pustaka dan studi lapangan. Untuk mendukung proses dalam penelitian ini, maka diperlukan beberapa rujukan yang di gunakan baik dari buku-buku yang mendukung dan jurnal-jurnal elektronik yang mencakup dan berkaitan dengan variabel penelitian ini. Dalam penelitian ini yang ditetapkan sebagai subyek penelitian adalah siswa kelas 1 B SD 200508 Sihitang yang berlokasi di Sihitang

\section{HASIL DAN PEMBAHASAN}

\section{Pengertian Bilangan dan Angka}

Bilangan adalah suatu konsep matematika yang digunakan untuk pencacahan dan pengukuran. Bilangan bersifat abstrak. Bilangan memberikan keterangan mengenai banyaknya sesuatu. Bilangan dan angka merupakan dua hal yang berbeda. Bilangan mewakili banyaknya suatu benda. Simbol atupun lambang yang digunakan untuk mewakili suatu bilangan disebut sebagai lambang bilangan atau angka. Angka adalah suatu lambang tertulis sebagai anggota dari suatu sistem penghitungan dan pengukuran.

Berdasarkan beberapa defenisi di atas disimpulkan bahwa bilangan dan angka adalah yang berbeda. Bilangan adalah konsep matematika yang digunakan untuk pencacahan dan pengukuran yang dapat dioperasionalkan secara matematik. Angka adalah lambang dari bilangan tersebut dan merupakan konsep matematika yang digunakan dalam pencacahan dan pengukuran.

Copyright @ 2020 , Universitas Muhammadiyah Metro| 43 
J-SANAK: Jurnal Kajian Anak

(p-ISSN: 2686-5343 le-ISSN: 2715-7989)

Vol. (2)(01), (Juli-Desember) (2020), (Halaman)(40-48)

DOI: https://doi.org/10.24127/j-sanak.v2i01.193

\section{Pengertian Kemampuan Mengenal Angka}

Secara umum konsep matematika pada anak usia dini menurut (Suyanto, 2003) meliputi hal-hal sebagai berikut.

a. Memilih, membandingkan dan mengurutkan, misalnya memilih balok yang pendek diteruskan ke yang lebih panjang sehingga membentuk urutan dari yang paling pendek ke yang paling panjang.

b. Klasifikasi, yaitu mengelompokkan benda-benda kedalam beberapa kelompok berdasarkan ukuran dan bentuknya.

c. Menghitung, yaitu menghubungkan antara konsep benda dengan konsep bilangan.

d. Angka, yaitu simbol dari kuantitas. Anak dapat menghubungkan antara banyaknya benda dengan simbol angka.

e. Pengukuran, anak dapat mengukur ukuran suatu benda dengan berbagai cara, baik dengan ukuran non standar (kaki dan jengkal) maupun standar (penggaris atau meteran).

f. Geometri, yaitu mengenal bentuk, luas, volume dan area.

g. Membuat grafik, misalnya guru membagi kartu merah, hijau dan kuning untuk anak yang suka apel, mangga dan pisang. Guru menyuruh anak untuk menempelkan pada papan tulis yang telah diberi sumbu datar (X) dan tegak (Y) sehingga akan tampak gambaran tentang banyaknya anak yang suka buah-buahan tersebut.

h. Pola, yaitu membentuk pola, misalnya guru memberi 1,3,6 lalu anak melanjutkan dengan suatu pola tertentu biasa 1,3,6 atau 3,6,1.

i. Problem solving, yaitu kemampuan memecahkan persoalan sederhana yang melibatkan bilangan dan operasi bilangan.

\section{Karakteristik dan Bentuk-bentuk Media pembelajaran}

Media adalah alat saluran komunikasi. Kata media berasal dari bahasa latin yang merupakan bentuk jamak dari medium. Secara harfiah, media berarti perantara, yaitu perantara antara sumber pesan dan penerima pesan (Indriana, 2011). Media adalah sesuatu yang terletak antara dua pihak, sedangkan (Longman, 1987) mengatakan bahwa media adalah suatu metode untuk memberikan informasi. Tidak semua media merupakan media pembelajaran tergantung pada pesan dan isi yang akan disampaikan. Dalam media pembelajaran, pesan yang disampaikan adalah pendidikan (Sanjaya, 2012). Media memiliki fungsi sebagai pembawa informasi dari sumber (guru) menuju penerima (siswa). Media adalah alat untuk membantu siswa dalam menerima dan mengolah informasi guna mencapai tujuan pembelajaran (Daryanto, 2011).

Menurut (Indriana, 2011), media harus mempunyai syarat yang harus dipenuhi agar bisa dibuat sebagai media pembelajaran, yaitu:

a. Rasional, yaitu sesuai dengan akal dan dapat dipikirkan oleh penggunanya. 
b. Ilmiah, yaitu sesuai dengan kaidah-kaidah ilmu pengetahuan.

c. Ekonomis, yaitu sesuai dengan kemampuan pembiyayaan sehingga lebih hemat dan efesien.

d. Praktis, yaitu dapat digunakan dalam kondisi praktis di sekolah dan dan bersifat sederhana.

Pada dasarnya media pembelajaran mempunyai lima bentuk dasar yaitu suara, gambar, grafik, garis dan gerakan (Indriana, 2011). Berdasarkan bentuk informasi yang digunakan, media pembelajaran dibagi dalam lima macam, yaitu: media visual diam, media visual bergerak, media audio, media audiovisual, dan audiovisual gerak.

Adapun menurut (Sanjaya, 2012) juga membagi media berdasarkan kemampuan jangkauannya. Pertama, media yang mempunyai daya liput dan serentak seperti radio dan televisi. Kedua, media yang daya liputnya terbatas oleh ruang dan waktu seperti film dan video. Berdasarkan bentuknya, media pembelajaran dapat berupa media ceta, media pameran, media yang diproyeksikan, rekaman audio, gambar bergerak, dan media berbasis komputer. Dengan menganalisis media melalui bentuk dan cara penyajian, mengklasifikasikan media pembelajaran sebagai berikut:
a. Grafis, bahan cetak, dan gambar diam
b. Media proyeksi diam
c. Media audio
d. Media gambar hidup/film, media televisi dan media multimedia.

\section{Pengertian Media Gambar}

Media grafis dalam konteks media pembelajaran, adalah media yang mengkomunikasikan data dan fakta, gagasan serta ide-ide melalui gambar dan katakata. Menurut (Sanjaya, 2012) yang termasuk media grafis adalah bagan, poster, karikatur, grafik serta gambar dan photo. Gambar adalah hasil coretan tangan manusia baik secara manual atau memakai alat modren, sedangkan photo merupakan hasil dari fotografi.

Gambar merupakan media yang umum dipakai untuk berbagai macam kegiatan pembelajaran, gambar yang baik bukan hanya dapat menyampaikan saja tetapi dapat digunakan untuk melatih keterampilan berpikir serta dapat mengembangkan kemampuan imajinasi anak. Jika diberikan sebuah gambar, anak dapat menceritakan kejadian yang nampak pada gambar sesuai dengan persepsinya.

Penggunaan media gambar sebagai sebuah media pembelajaran mempunyai beberapa manfaat dan kelebihan.

a. Gambar dapat menghilangkan verbalisme

b. Gambar dapat mengatasi batasan ruang dan waktu 
c. Gambar merupakan media yang mudah diperoleh, harganya murah serta penggunaannya tidak memerlukan peralatan khusus

Adanya kelebihan di atas membuktikan penggunaan media gambar dalam pembelajaran juga mempunyai keterbatasan sebagai berikut.

a. Gambar media visual yang hanya mengendalikan indera penglihatan, oleh sebab itu tidak memberikan informasi yang mendalam tentang suatu hal. Media gambar hanya dapat digunakan oleh orang yang mempunyai indera penglihatan yang normal dan sehat.

b. Tidak seluruh bahan pelajaran dapat disajikan dengan media ini. Bahan pelajaran mengenai prosesyang mengandung gerakan-gerakan tertentu kurang efektif disajikan dengan media gambar.

\section{Karakteristik Pengenalan Angka Pada Anak Usia 5-6 Tahun}

Menurut (Sujiono, 2011), perkembangan kognitif anak usia 5-6 tahun adalah dapat mengurutkan obyek yang tepat, mempunyai ketertarikan dengan jumlah dan para beberapa anak sudah mulai menggunakan angka, jumlah dan panjang. (Rasyid, dkk, 2009) setelah mengelola pendapat dari para ahli, mengatakan bahwa kecerdasan logika dan matematika dengan substansi pengembangan menentukan hubungan sebab akibat, anak umur 4-5 tahun tahun mempunyai indikator perkembangan dapat mengulang angka 1-10 tanpa salah. Pada anak dengan umur 5-6 tahun anak sudah bisa menguasai konsep bilangan, melakukan operasi hitung sesuai dengan aturannya.

Dalam Buku Pedoman Pengembangan Program Pembelajaran di kelas 1 SD (2010: 14), dikatakan bahwa pada lingkup perkembangan konsep bilangan dan angka, anak usia 5-6 tahun mempunyai tingkat perkembangan sebagai berikut:

a. Menyebut angka 1-10 dengan indikator

1) Membilang/ menyebut urutan bilangan dari 1-10

2) Membilang (mengenal konsep bilangan dengan benda) sampai 10

3) Menunjuk angka 1-10

4) Membuat urutan bilangan 1-10 dengan benda-benda

5) Meniru angka 1-10

b. Mencocokkan bilangan dan angkanya dengan indikator

1) Menghubungkan angka dengan benda-benda sampai dengan 10, dan

2) Mencocokkan bilangan dengan angka

Sedangkan penelitian yang dilaksanakan di SD Sihitang yang beralamat di Sihitang Jl. H.T. Rizal Nurdin KM.4,5 Padangsedimpuan Tenggara. Sekolah ini terletak di tengah-tengah kampung sihitang, tepatnya di Sihitang. Tenaga pendidik di SD Sihitang terdiri dari beberapa kepala sekolah yang merangkap sebagai guru dan satu guru kelas $1 \mathrm{~B}$. Ada seorang pegawai yang bertugas menjaga kebersihan lingkungan sekolah. Pegawai tersebut sekaligus membantu menyiapkan minum, 
snack dan makan untuk siswa. Siswa kelas 1 B SD 200508 Sihitang mempunyai murid sebanyak 15 anak, terdiri dari 10 anak laki-laki dan 5 anak perempuan.

Pembelajaran mengenal angka dilakukan oleh guru dengan menggunakan papan tulis. Kadang-kadang guru juga menggunakan media kartu angka dan gambar yang dimiliki oleh sekolah. Anak-anak tampak kurang antusias. Perhatian anak kurang fokus dan anak banyak bermain dengan temannya. Berdasarkan pengamatan yang telah dilakukan sebelumnya, kemampuan anak mengenal angka 1-10 di kelas 1 B SD Sihitang masih kurang maksimal karena metode pembelajaran yang kurang menarik. Untuk mengatasi kesulitan tersebut diperlukan suatu kegiatan yang dapat membantu perbaikan peningkatan kemampuan anak dalam mengingat bentuk angka. Kegiatan tersebut adalah dengan mengingat suatu bentuk benda yang konkret yang diwujudkan dalam bentuk gambar.

\section{KESIMPULAN}

Berdasarkan hasil penelitian dan pembahasan yang telah dilakukan dapat disimpulkan bahwa pembelajaran dengan media gambar dapat meningkatkan kemampuan mengenal angka 1-10 di kelas 1 B SD Sihitang. Hal ini ditunjukkan dari adanya peningkatan kemampuan menyebut angka 1-10, kemampuan menjodohkan angka dengan gambar dan kemampuan menulis angka. Sedangkan sarannya dengan adanya media gambar dapat dijadikan alternatif pembelajaran untuk meningkatkan kemampuan anak mengenal angka di Kelas 1 B Sihitang. Guru dapat mencari bentuk-bentuk gambar lain yang mungkin lebih sesuai dengan lingkungan pembelajaran setempat. Kemudian, untuk penelitian selanjutnya yang berkaitan dengan cara meningkatkan kemampuan mengenal angka 10 dengan media gambar ini masih mempunyai banyak kekurangan yang harus diperbaiki. Peneliti selanjutnya dapat berinovasi dengan gambar.

\section{E. DAFTAR PUSTAKA}

Ahmadi, A. (2009). Psikologi Umum. In Jakarta: Rineka Cipta.

Daryanto. (2012). Media Pembelajaran. Bandung: Sarana Tutorial Nurani Sejahtera.

Hasiana, I., \& Wirastania, A. (2017). Pengaruh Musik Dalam Mengembangkan Kemampuan Mengenal Bilangan Siswa Kelompok A di TK Lintang Surabaya. Jurnal Obsesi: Jurnal Pendidikan Anak Usia Dini, 1(2), 131. https://doi.org/10.31004/obsesi.v1i2.25

Indriana, D. (2011). Ragam Alat Bantu Media Pengajaran. Yogyakarta: Diva Press. Longman. (1987). Dictionary of Contemporary English. Suffolk: Richard Clay Ltd. Nasional, K. P. (2009). Permendiknas Nomor 58 Tahun 2009. Jakarta: Kementerian Pendidikan Nasional Republik Indonesia.

Ningrum, F. D. F. (2019). Penggunaan Metode Bermain Kartu Angka Bergambar Untuk Meningkatkan Kemampuan Mengenal Angka 1-10 Pada Kelompok A di PAUD An-Nahdliyah Kenongo Tulangan Sidoarjo. Digilib.Uinsby. 
J-SANAK: Jurnal Kajian Anak

(p-ISSN: 2686-5343 le-ISSN: 2715-7989)

Vol. (2)(01), (Juli-Desember) (2020), (Halaman)(40-48)

DOI: https://doi.org/10.24127/j-sanak.v2i01.193

Qur'aini, A. W. (2015). Meningkatkan Kemampuan Mengenal Angka 1-10 Menggunakan Media Bowang Pada Anak Kelompok A TK Taman Indria Kecamatan Kota, Kota Kediri. Simki.Unpkediri.Ac.Id. http://simki.unpkediri.ac.id/mahasiswa/file_artikel/2015/11.1.01.11.0004.pdf Sanjaya, W. (2012). Media Komunikasi Pembelajaran. Jakarta: Kencana Prenada Media Group.

Sujiono, Y. N. (2011). Konsep Dasar Pendidikan Anak Usia Dini. 